Received Date : 18-Dec-2015

Revised Date : 09-May-2016

Accepted Date : 10-May-2016

Article type : News and Commentaries

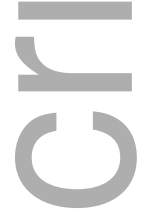

\title{
Global Perceptions of Food Allergy Thresholds in 16 Countries
}

Mary Jane Marchisotto ${ }^{1} \&$ Laurie Harada ${ }^{2}$, Jesse Blumenstock ${ }^{3}$, Lucy Bilaver ${ }^{4,5}$, Susan Waserman ${ }^{6}$, Scott

Sicherer $^{7}$, Yanne Boloh ${ }^{8}$, Lynne Regent ${ }^{9}$, Maria Said ${ }^{10}$; Sabine Schnadt ${ }^{11}$, Katrina Allen ${ }^{12}$, Antonella

Muraro $^{13}$, Steve Taylor ${ }^{14}$, Ruchi S. Gupta ${ }^{3,15}$

${ }^{1}$ Food Allergy Research and Education, Inc, New York, NY; ${ }^{2}$ Food Allergy Canada (formerly Anaphylaxis Canada),

Toronto, Canada; ${ }^{3}$ Northwestern University Feinberg School of Medicine, Chicago, IL; ${ }^{4}$ Department of Public

Health, Northern Illinois University, DeKalb, IL; ${ }^{5}$ Chapin Hall of the University of Chicago, Chicago, IL; ${ }^{6}$ Division of Allergy and Clinical Immunology, McMaster University, Hamilton, ON; ${ }^{7}$ Icahn School of Medicine at Mount Sinai, New York, NY; ${ }^{8}$ Philéas Info, St Mars d'Outillé, France $;{ }^{9}$ Anaphylaxis Campaign, Farnborough, UK ; ${ }^{10}$ Allergy \& Anaphylaxis Australia, Castle Hill, NSW, Australia ; ${ }^{11}$ Deutscher Allergie- und Asthmabund e.V. (DAAB), Mönchengladbach, Germany; ${ }^{12}$ Centre of Food and Allergy Research, Murdoch Children's Research Institute, The Royal Children's Hospital, Melbourne 3052, Australia; Department of Allergy and Clinical Immunology, The Royal Children's Hospital, Melbourne 3052, Australia; Department of Gastroenterology and Clinical Nutrition, The Royal Children's Hospital, Melbourne 3052, Australia; Department of Paediatrics, The Royal Children's Hospital, University of Melbourne, Melbourne 3052, Australia; Institute of Inflammation and Repair, University of Manchester, Manchester, UK; ${ }^{13}$ Department of Pediatrics, University of Padua, Padua, Italy;

${ }^{14}$ Food Allergy Research \& Resource Program (FARRP), University of Nebraska, Lincoln, NE; ${ }^{15}$ Ann \& Robert H. Lurie Children's Hospital of Chicago, Chicago, IL.

\section{Corresponding Author:}

Ruchi Gupta, M.D., M.P.H.

Associate Professor of Pediatrics

This is the author manuscript accepted for publication and has undergone full peer review but has not been through the copyediting, typesetting, pagination and proofreading process, which may lead to differences between this version and the Version of Record. Please cite this article as doi: $\underline{10.1111 / \text { ALL.12933 }}$

This article is protected by copyright. All rights reserved 
Ann and Robert H. Lurie Children's Hospital of Chicago

Northwestern Feinberg School of Medicine

750 N. Lake Shore Drive, Chicago, IL 60611

Ph. (312) 503-5581

Fax (312) 503-2777

E-mail r-gupta@northwestern.edu

$\square$
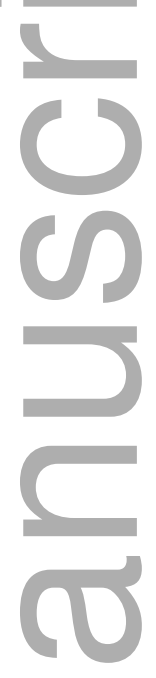

$+\sqrt{10}$
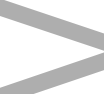

ABSTRACT

\section{Background}

Food allergy is a growing global health issue that affects daily life and food purchasing habits. Quality data on the global consumer perspective of food allergy is limited, particularly about thresholds and food labeling risk. Many individuals with food allergy are counseled that small amounts of allergen can potentially cause life-threatening reactions, and to avoid foods with Precautionary Advisory Labeling (PAL). The purpose of this study was to understand attitudes of consumers about food allergy thresholds and food purchasing habits related to PAL in sixteen countries.

\section{Methods}


A questionnaire was distributed by patient support groups in 16 countries to consumers with food allergy. The questionnaire gathered opinions about food allergy thresholds and PAL purchasing habits.

\section{Results}

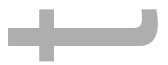

9,689 respondents from 16 countries completed the survey. $19 \%$ of respondents stated they would purchase a food containing their allergen if the amount present would not cause a reaction and $3 \%$ would purchase a food if the amount of allergen present would cause a mild reaction. When asked about labeling, $16 \%$ of respondents reported that they would purchase food with a "may contain" statement, $25 \%$ would purchase food labeled "may contain traces of allergen", and $41 \%$ would purchase products labeled "manufactured in a facility that also processes allergen".

\section{Conclusions}

Findings suggest that understanding of food allergen thresholds and precautionary allergen labelling is limited and consumers may develop their own risk assessment based on labels, which are not based on clinical validation. Improved awareness of thresholds, standardization of PAL, and clinical validation are needed globally.

Keywords:

Food Allergy, Global, Thresholds, Food Allergens, Precautionary Allergen Labeling

Abstract Word Count: 250

Manuscript Word Count: 1478

\section{Introduction}


Childhood food allergy is a significant public health issue with prevalence rates as high as $10 \%$ among children in some countries. $(1,2)$ While the quality and quantity of global data on childhood food allergy has increased in recent years, knowledge on consumer perceptions of issues affecting management is lacking. $(3,4)$ Allergic reactions to food can vary from mild, to life-threatening. As a result, the standard recommendation is to strictly avoid the food allergen, which can be complicated when purchasing packaged food.

The food industry in most countries is required to label the presence of the most common food allergens when they are ingredients in packaged foods; however, they may voluntarily add Precautionary Allergen Labeling (PAL). These statements, such as "may contain..." or "processed in a facility that manufactures..." are unregulated and it is unknown how many products with PAL actually contain trace levels. Consumers must make their own decisions on how to interpret these PAL statements, which can lead to food restrictions that affect the daily lives and well-being of consumers and caregivers. $(5,6)$

A greater understanding of food allergen thresholds (the lowest amount of a food allergen that can cause an allergic reaction) is important to a variety of food allergy stakeholders.(7) In 2011, an expert panel was assembled to establish reference doses for 11 allergenic foods as part of the VITAL (Voluntary Incidental Trace Allergen Labeling) program. The doses were obtained from clinical challenges of individuals to establish an eliciting dose for each food at which only a predicted $1-3 \%$ of the population would react.(8)

This study represents the first of its kind to examine differences in perceptions about food allergen thresholds and PAL from the perspective of consumers in 16 countries across the world.

\section{METHODS}

Patient support organizations from sixteen countries (Australia, Canada, Chile, France, Germany, Ireland, Israel, Italy, Japan, Mexico, New Zealand, South Africa, Spain, Netherlands, UK, US) recruited adult participants for the population-based online survey. Most groups used their internal communication systems to recruit participants.

Subjects were invited to participate if they had a food allergy, someone in their family/household had a food allergy, or they were the caregiver of someone with a food allergy. Data was collected data for a two-week period. Sample sizes ranged from 36 participants in 
South Africa to 5,578 in the United States (Table 1). Launch dates varied across countries, with data collection occurring between February 2013 and April 2014.

The survey was based on an instrument developed by the US patient advocacy organization, Food Allergy Research \& Education (FARE). The FARE survey asked questions about the influence of food labeling on purchasing habits, knowledge about thresholds, and opinions about thresholds and food choices (E1). In addition, the survey captured information about the type of food allergies, history of severe reactions, and source of food allergy diagnosis. Only minor revisions to questions were made to reflect local labelling practices in the global survey.

All participating organizations were provided the English version of the questionnaire for review before translation into their local language. The survey was completed in eight different languages (English, French, Spanish, Italian, Hebrew, Dutch, German, and Japanese).

SurveyMonkey was used to administer the online survey. Individual responses were cleaned, translated into English, and summarized by each country's patient organization. Country-level results for 9,689 participants were analyzed ${ }^{1}$. Weighted averages of responses to each survey question were calculated. Chi-square tests of association were used to assess significant differences across countries in the primary measures of consumer perceptions.

\section{RESULTS}

Table 1 presents the characteristics of respondents to the global survey. In all but two countries (Germany and South Africa), the highest proportion of respondents reported having a child in the household with a food allergy. Respondents in New Zealand and the United States had the highest percentage of respondents reporting more than one child with a food allergy in the home $(20 \%)$.

Experience with severe reactions varied considerably from only $28 \%$ of respondents in Mexico to $84 \%$ of respondents in the Netherlands (weighted average 67\%). Peanut was the most common allergen reported in nine of 16 countries. The highest reported rate was $91 \%$ of respondents in the US. Five of 16 countries (Chile, 81\%; Israel, 63\%; Italy, 55\%; Mexico, 84\%; Spain, $53 \%$ ) reported milk to be the most common allergen while egg was the most common

\footnotetext{
${ }^{1}$ A complete copy of the country-level dataset is available by request to the corresponding author.
} 
allergen in Japan (59\%) and tree nut or other nuts were most common in France (53\%). In all but two countries, allergists were the most common source of food allergy diagnosis.

Knowledge of food allergy thresholds by respondents is presented in an online supplemental table (E2). The primary response variables by country are presented in Table 2. Less than one-quarter of participants in 11 of 16 countries (weighted average of 19\%) reported that they would be willing to purchase foods containing their allergen if the amount would be incapable of causing an allergic reaction. Respondents in Japan were the most willing to purchase under these conditions (44\%) while respondents in Italy were the least willing (14\%). When asked if they would purchase foods containing their allergen if it were capable of only triggering a mild reaction, rates were lower across all countries with a weighted average of $3 \%$. Respondents in Japan were again most willing to accept this risk of a mild reaction (15\%) while respondents in Spain were least willing $(1 \%)$.

Opinions about purchasing packaged foods with the precautionary label "may contain allergens" were similar. Overall, $16 \%$ of respondents reported that they would be willing to purchase such products with South Africa reporting the highest rate (53\%) and the Spain reporting the lowest (6\%). Slightly higher rates of participants would purchase a food labeled, "may contain traces of allergen" ( $25 \%$ weighted average) and the highest proportion of respondents would purchase products labeled "manufactured in a facility that also processes allergen" ( $41 \%$ weighted average). Significant differences by country were identified for each of the primary response variables $(\mathrm{p}<0.001)$.

\section{DISCUSSION}

This study represents the first to explore global consumer perceptions of food allergen thresholds and food allergen labeling. Consumers would purchase food with PAL ranging from $16 \%$ "may contain allergens" and higher proportions would purchase products with other precautionary labels. Nineteen percent reported they would purchase foods that contained allergen at levels not capable of triggering a reaction, while only $3 \%$ would purchase foods that contained allergens capable of triggering a mild reaction. Consumers seem to trust these labels to estimate allergen reaction risk. This risk assessment seems to occur at different rates depending on country and the PAL statement used..

While PAL statements warn consumers of potential risk from consuming packaged foods, there are no standard regulations regarding these labels and use of PAL is voluntary. Previous 
studies have shown that there is little correlation between the amount of allergen actually present in a product and the PAL statement used.(9-13) Therefore, increases in the use of PAL have escalated confusion, risk-taking, and anxiety, potentially placing severe restrictions on food choices. $(11,14)$

Recent research on food allergen thresholds has shown that a large majority of individuals with food allergy could tolerate small amounts of their allergen. $(8,15-17)$ A validated labeling process would represent a much lower percentage of foods than are currently labelled with meaningless PAL statements, allowing for greater diversity of dietary choice. These policies for labeling based on thresholds would empower consumers with food allergies to make safe food purchasing choices without anxiety about complete restriction, increasing quality of life and decreasing caregiver burden.

Several limitations of the study should be noted. All data were self-reported, which is subject to bias. It is not clear if the results are reflective of the general population, as the respondents were not recruited to be representative. Often people who respond to surveys through consumer groups are skewed toward more educated, affluent, and severely affected populations. The survey's definition of severe food allergy included swelling of the tongue, lips, face, or throat, which are not always included as severe reactions. This may have inflated numbers of severe allergy.

With consumers developing their own risk assessment through the purchase of food products, it is imperative that we educate consumers with food allergy on thresholds and PAL, develop effective policies for labeling dependent on validated thresholds, and change the way physicians advise their patients about avoidance. Empowering consumers with more information from industry on the levels of allergen in packaged food may allow consumers to make decisions that are more informed and increase self-efficacy with regard to management behaviors. This could reduce fear and anxiety around consumption of packaged foods and allow consumers greater options for purchasing foods, thus improving quality of life. As the discussion on standardizing PAL and allergen thresholds continues, all stakeholders, including consumers, physicians, and food industry need to be engaged to build understanding and trust in labels based on validated allergen thresholds.

\section{ACKNOWLEDGEMENTS:}


Food Allergy Research \& Education (FARE) and Food Allergy Canada designed and led the study, collection, management, analysis and decision to submit the manuscript for publication. Allergy \& Anaphylaxis Australia, Anaphylaxis Campaign, and German Allergy and Asthma Association provided financial support and were involved in the decision to submit the manuscript.

Thank you to Nancy Gregory, Jennifer Jobrack, Bob Lake, and Julie Mendel Reinhard for development of the original FARE survey.

Funding provided by FARE, Mylan, Food Allergy Canada, The Anaphylaxis Campaign, AAI Anaphylaxis Australia, Inc., German Allergy and Asthma Association.

\section{References}

1. Osborne NJ, Koplin JJ, Martin PE, Gurrin LC, Lowe AJ, Matheson MC, et al. Prevalence of challenge-proven $\operatorname{IgE}$-mediated food allergy using population-based sampling and predetermined challenge criteria in infants. J Allergy Clin Immunol 2011;127(3):668-676 e661-662.

2. Caffarelli C, Coscia A, Ridolo E, Povesi Dascola C, Gelmett C, Raggi V, et al. Parents' estimate of food allergy prevalence and management in Italian school-aged children. Pediatrics International 2011;53(4):505-510.

3. Prescott SL, Pawankar R, Allen KJ, Campbell DE, Sinn J, Fiocchi A, et al. A global survey of changing patterns of food allergy burden in children. World Allergy Organ J 2013;6(1):21.

4. McBride D, Keil T, Grabenhenrich L, Dubakiene R, Drasutiene G, Fiocchi A, et al. The EuroPrevall birth cohort study on food allergy: baseline characteristics of 12,000 newborns and their families from nine European countries. Pediatr Allergy Immunol 2012;23(3):230-239.

5. Boyce JA, Assa'ad A, Burks AW, Jones SM, Sampson HA, Wood RA, et al. Guidelines for the Diagnosis and Management of Food Allergy in the United States: Summary of the NIAID-Sponsored Expert Panel Report. J Allergy Clin Immunol 2010;126(6):1105-1118. 
6. Muraro A, Roberts G, Worm M, Bilò MB, Brockow K, Fernández Rivas M, et al. Anaphylaxis: guidelines from the European Academy of Allergy and Clinical Immunology. Allergy 2014;69(8):10261045.

7. Crevel RW, Ballmer-Weber BK, Holzhauser T, Hourihane JO, Knulst AC, Mackie AR, et al. Thresholds for food allergens and their value to different stakeholders. Allergy 2008;63(5):597-609.

8. Taylor SL, Baumert JL, Kruizinga AG, Remington BC, Crevel RW, Brooke-Taylor S, et al. Establishment of Reference Doses for residues of allergenic foods: report of the VITAL Expert Panel. Food Chem Toxicol 2014;63:9-17.

9. Ford LS, Taylor SL, Pacenza R, Niemann LM, Lambrecht DM, Sicherer SH. Food allergen advisory labeling and product contamination with egg, milk, and peanut. Journal of Allergy and Clinical Immunology 2010;126(2):384-385.

10. Pele M, Brohée M, Anklam E, Hengel AJV. Peanut and hazelnut traces in cookies and chocolates: relationship between analytical results and declaration of food allergens on product labels. Food additives and contaminants 2007;24(12):1334-1344.

11. Hefle SL, Furlong TJ, Niemann L, Lemon-Mule H, Sicherer S, Taylor SL. Consumer attitudes and risks associated with packaged foods having advisory labeling regarding the presence of peanuts. Journal of Allergy and Clinical Immunology 2007;120(1):171-176.

12. Crotty MP, Taylor SL. Risks associated with foods having advisory milk labeling. J Allergy Clin Immunol 2010;125(4):935-937.

13. Remington BC, Baumert JL, Marx DB, Taylor SL. Quantitative risk assessment of foods containing peanut advisory labeling. Food Chem Toxicol 2013;62:179-187.

14. Sheth SS, Waserman S, Kagan R, Alizadehfar R, Primeau M-N, Elliot S, et al. Role of food labels in accidental exposures in food-allergic individuals in Canada. Annals of Allergy, Asthma \& Immunology 2010;104(1):60-65.

15. Allen KJ, Remington BC, Baumert JL, Crevel RW, Houben GF, Brooke-Taylor S, et al. Allergen reference doses for precautionary labeling (VITAL 2.0): clinical implications. J Allergy Clin Immunol 2014;133(1):156-164.16. Blom WM, Vlieg-Boerstra BJ, Kruizinga AG, van der Heide S, Houben 
GF, Dubois AE. Threshold dose distributions for 5 major allergenic foods in children. Journal of Allergy and Clinical Immunology 2013;131(1):172-179.

17. Zhu J, Pouillot R, Kwegyir-Afful EK, Luccioli S, Gendel SM. A retrospective analysis of allergic reaction severities and minimal eliciting doses for peanut, milk, egg, and soy oral food challenges. Food and Chemical Toxicology 2015;80:92-100.

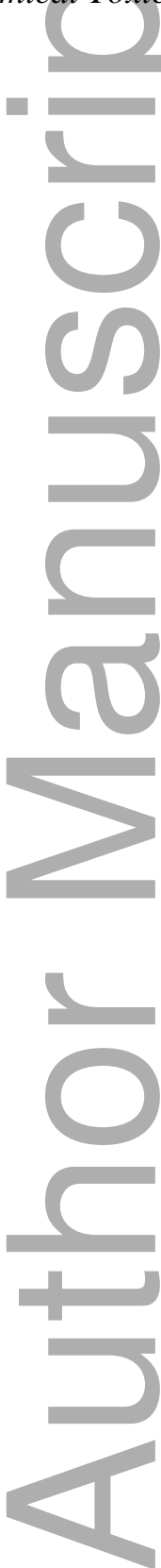




\begin{tabular}{|c|c|c|c|c|c|c|c|}
\hline Country & $\begin{array}{c}\text { Respondent } \\
\text { with a food } \\
\text { allergy }\end{array}$ & $\begin{array}{c}\text { Adult in } \\
\text { household } \\
\text { with food } \\
\text { allergy }\end{array}$ & $\begin{array}{c}\text { Child in } \\
\text { household } \\
\text { with food } \\
\text { allergy }\end{array}$ & $\begin{array}{c}2 \text { or more } \\
\text { children } \\
\text { with food } \\
\text { allergy }\end{array}$ & $\begin{array}{l}\text { Anyone in household } \\
\text { with history of } \\
\text { severe }^{\text {a food allergy }} \\
\text { reaction }\end{array}$ & $\begin{array}{c}\text { Top } 3 \text { Most } \\
\text { Common Food } \\
\text { Allergen }\end{array}$ & $\begin{array}{c}\text { Most Common } \\
\text { Source of } \\
\text { Diagnosis }\end{array}$ \\
\hline $\begin{array}{l}\text { Australia } \\
(\mathrm{n}=401)\end{array}$ & 15 & & 89 & 17 & 68 & $\begin{array}{l}\text { Peanut }(74 \%) \\
\text { Tree Nuts }(64 \%) \\
\text { Eggs }(46 \%)\end{array}$ & Allergist (86\%) \\
\hline $\begin{array}{c}\text { Canada } \\
(\mathrm{n}=1,263)\end{array}$ & 31 & & 77 & 10 & 71 & $\begin{array}{l}\text { Peanut }(75 \%) \\
\text { Tree Nuts }(62 \%) \\
\text { Eggs }(26 \%)\end{array}$ & Allergist (89\%) \\
\hline $\begin{array}{l}\text { Chile } \\
(\mathrm{n}=183)\end{array}$ & 17 & 34 & 89 & 16 & 34 & $\begin{array}{l}\text { Milk }(81 \%) \\
\text { Soy }(50 \%) \\
\text { Peanut }(46 \%)\end{array}$ & $\begin{array}{l}\text { Digestive/GI } \\
(\mathbf{4 5 \% )}\end{array}$ \\
\hline $\begin{array}{l}\text { France } \\
(n=97)\end{array}$ & 27 & 40 & 75 & 14 & 63 & $\begin{array}{l}\text { Tree Nuts }(53 \%) \\
\text { Peanut }(52 \%) \\
\text { Eggs }(42 \%)\end{array}$ & Allergist (84\%) \\
\hline $\begin{array}{l}\text { Germany } \\
(n=487)\end{array}$ & 63 & 68 & 45 & 7 & 58 & $\begin{array}{l}\text { Peanut }(50 \%) \\
\text { Tree Nuts }(49 \%) \\
\text { Milk (32\%) }\end{array}$ & Allergist (69\%) \\
\hline $\begin{array}{l}\text { Ireland } \\
(\mathrm{n}=87)\end{array}$ & 29 & & 78 & 13 & 78 & $\begin{array}{l}\text { Peanut }(69 \%) \\
\text { Tree Nuts }(66 \%) \\
\text { Eggs }(44 \%)\end{array}$ & Allergist (63\%) \\
\hline $\begin{array}{c}\text { Israel } \\
(\mathrm{n}=349)\end{array}$ & 5 & 21 & 97 & 12 & 74 & $\begin{array}{l}\text { Milk (63\%) } \\
\text { Peanut (39\%) } \\
\text { Tree Nuts (28\%) }\end{array}$ & Allergist (86\%) \\
\hline $\begin{array}{l}\text { Italy } \\
(\mathrm{n}=85)\end{array}$ & 29 & & 60 & 9 & 64 & $\begin{array}{l}\text { Milk (55\%) } \\
\text { Tree Nuts (41\%) } \\
\text { Peanut (32\%) }\end{array}$ & Allergist (78\%) \\
\hline $\begin{array}{c}\text { Japan } \\
(\mathrm{n}=285)\end{array}$ & 31 & 45 & 73 & 16 & 56 & $\begin{array}{l}\text { Eggs }(59 \%) \\
\text { Milk }(46 \%) \\
\text { Peanut }(29 \%)\end{array}$ & Allergist (53\%) \\
\hline $\begin{array}{l}\text { Mexico } \\
(\mathrm{n}=264)\end{array}$ & 8 & 45 & 83 & 17 & 28 & $\begin{array}{l}\text { Milk (84\%) } \\
\text { Eggs }(48 \%) \\
\text { Soy }(47 \%)\end{array}$ & Allergist (61\%) \\
\hline $\begin{array}{c}\text { New } \\
\text { Zealand } \\
(n=183)\end{array}$ & 27 & 38 & 78 & 20 & 63 & $\begin{array}{l}\text { Peanut }(61 \%) \\
\text { Tree Nuts }(56 \%) \\
\text { Eggs }(52 \%)\end{array}$ & Allergist (66\%) \\
\hline South Africa & 44 & 56 & 47 & 19 & 56 & Peanut $(42 \%)$ & Family Physician \\
\hline
\end{tabular}

This article is protected by copyright. All rights reserved 


\begin{tabular}{|c|c|c|c|c|c|c|c|}
\hline$(\mathrm{n}=36)$ & & & & & & $\begin{array}{l}\text { Milk (39\%) } \\
\text { Wheat }(36 \%)\end{array}$ & $(33 \%)$ \\
\hline $\begin{array}{c}\text { Spain } \\
(\mathrm{n}=577)\end{array}$ & 16 & 37 & 86 & 9 & 57 & $\begin{array}{l}\text { Milk (53\%) } \\
\text { Eggs }(48 \%) \\
\text { Tree Nuts (43\%) }\end{array}$ & Allergist (58\%) \\
\hline $\begin{array}{c}\text { The } \\
\text { Netherlands } \\
(\mathrm{n}=179)\end{array}$ & 44 & 56 & 63 & 9 & 84 & $\begin{array}{l}\text { Tree Nuts }(66 \%) \\
\text { Peanut }(66 \%) \\
\text { Milk/Eggs }(23 \%)\end{array}$ & Allergist (69\%) \\
\hline $\begin{array}{c}\text { UK } \\
(\mathrm{n}=171)\end{array}$ & 41 & & 55 & 8 & 80 & $\begin{array}{l}\text { Peanut }(63 \%) \\
\text { Tree Nut }(57 \%) \\
\text { Eggs }(26 \%)\end{array}$ & Allergist (54\%) \\
\hline $\begin{array}{c}\text { US } \\
(n=5,578)\end{array}$ & 20 & 34 & 85 & 20 & 70 & $\begin{array}{l}\text { Peanut }(91 \%) \\
\text { Tree Nuts }(81 \%) \\
\text { Milk }(43 \%)\end{array}$ & Allergist (88\%) \\
\hline $\begin{array}{l}\text { Weighted } \\
\text { Average }\end{array}$ & 24 & 39 & 81 & 16 & 67 & $\begin{array}{l}\text { Peanut }(74 \%) \\
\text { Tree Nuts }(67 \%) \\
\text { Milk }(42 \%)\end{array}$ & Allergist (81\%) \\
\hline
\end{tabular}

${ }^{a}$ Severe food allergy was described as anaphylaxis; difficulty breathing; a drop in blood pressure; swelling of the tongue, lips, face or throat; loss of consciousness; or shock

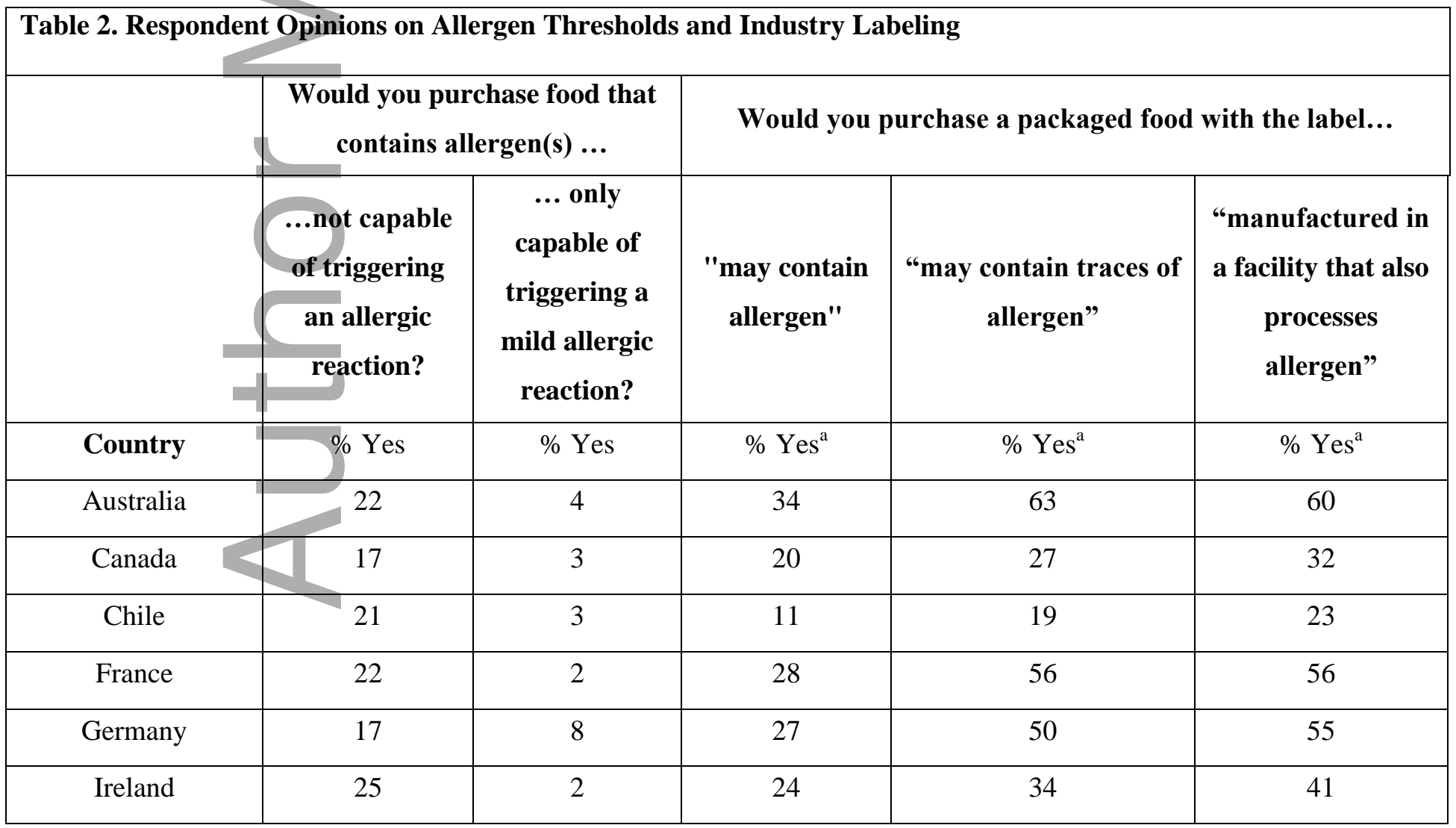

This article is protected by copyright. All rights reserved 


\begin{tabular}{|c|c|c|c|c|c|}
\hline Israel & 39 & 6 & 28 & 39 & 63 \\
\hline Italy & 14 & 2 & 24 & 39 & 39 \\
\hline Japan & 44 & 15 & 35 & 43 & 72 \\
\hline Mexico & 19 & 5 & 13 & 21 & $\mathrm{~N}^{\mathrm{b}}$ \\
\hline New Zealand & 31 & 8 & 44 & 67 & 76 \\
\hline South Africa & 36 & 8 & 53 & 25 & 25 \\
\hline Spain & 16 & 1 & 6 & 22 & 60 \\
\hline The Netherlands & 30 & 10 & 31 & 53 & 44 \\
\hline UK & 17 & 2 & 28 & 14 & 41 \\
\hline US & 17 & 2 & 10 & 16 & 25 \\
\hline
\end{tabular}




\section{University Library}

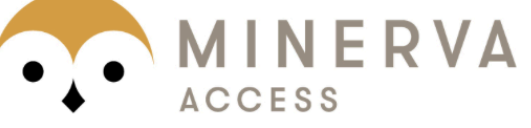

A gateway to Melbourne's research publications

Minerva Access is the Institutional Repository of The University of Melbourne

Author/s:

Marchisotto, MJ;Harada, L;Blumenstock, JA;Bilaver, LA;Waserman, S;Sicherer, S;Boloh, Y;Regent, L;Said, M;Schnadt, S;Allen, KJ;Muraro, A;Taylor, SL;Gupta, RS

Title:

Global perceptions of food allergy thresholds in 16 countries

Date:

2016-08-01

Citation:

Marchisotto, M. J., Harada, L., Blumenstock, J. A., Bilaver, L. A., Waserman, S., Sicherer, S., Boloh, Y., Regent, L., Said, M., Schnadt, S., Allen, K. J., Muraro, A., Taylor, S. L. \& Gupta, R. S. (2016). Global perceptions of food allergy thresholds in 16 countries. ALLERGY, 71 (8), pp.1081-1085. https://doi.org/10.1111/all.12933.

Persistent Link:

http://hdl.handle.net/11343/291941 